\title{
Economic Potential of Renewable Energy in Vietnam's Power Sector
}

14 October 2008

\begin{abstract}
In this study we use the bottom-up Integrated Resource Planning model to examine the potential of renewable energy in Vietnam's power sector. In our scenario without renewables, coal provides $44 \%$ of electricity generated from 2010 to 2030 . The use of renewables could reduce that figure to $39 \%$, as well as decrease the sector's cumulative emission of $\mathrm{CO}_{2}$ by $8 \%, \mathrm{SO}_{2}$ by $3 \%$, and $\mathrm{NO} x \underline{x}$ by $4 \%$. In addition, it could avoid installing $4.4 \mathrm{GW}$ in fossil fuel generating capacity, conserve domestic coal, decrease coal and gases imports, and seek greater energy independence and security. Wind could become costcompetitive assuming high but plausible on fossil fuel prices, if the cost of the technology falls to $900 \mathrm{US} \$ / \mathrm{kW}$. For wood to compete at higher fossil fuel prices, the cost of its technology would have to fall to $1,500 \mathrm{US} \$ / \mathrm{kW}$.
\end{abstract}

Key words: integrated resource planning, renewable energy, electricity generation, Vietnam 


\section{Table of Contents}

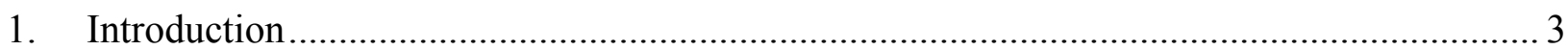

2. The power sector and renewables in Vietnam: status and perspectives ............................. 5

3. The Integrated Resource Planning (IRP) model ........................................................ 7

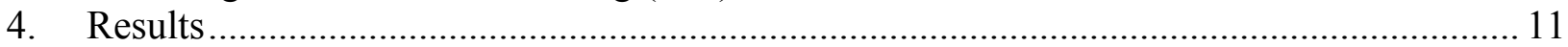

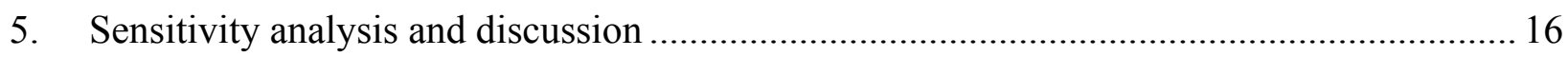

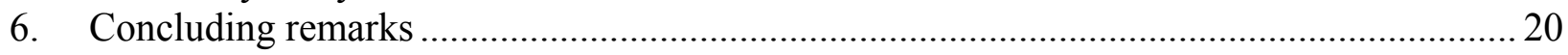




\section{Introduction}

The transformation to a mostly market-driven economy has led Vietnam to faster economic growth with annual rates of $7-8 \%$ during the last decade. The need for electricity services in Vietnam has been increasing in parallel with industrial development, migration to cities, and rising living standards. As discussed by Nguyen and Tran (2005), and Khanh (2007b), given the high growth of electricity generation in Vietnam, thermal power generation is likely to increase in the years to come. Coal is expected to be the dominant fuel for electricity generation from 2015 to 2030 . As a result, the share of $\mathrm{CO}_{2}$ emission coming from the power sector in the national $\mathrm{CO}_{2}$ emission inventory is expected to grow. Yet increasing the use of fossil fuels to meet growing worldwide demand for electricity, especially in developing countries, goes against the need to prevent dangerous climate change globally, and it has detrimental health and environmental effects locally.

There is an extensive literature on how to mitigate emissions by using different combinations of primary energy resources to generate electricity in Asia. Chattopadhyay, D (1994) analyzed some $\underline{\text { mitigation options such as switching cleaner fuels (i.e. from coal to natural gas) to reduce } \mathrm{CO}_{2}}$ emissions in India's power sector. Fernando, et al (1994) developed an integrated resource planning approach considering both supply and demand side options to address the twin problems of environmental degradation and capital costs in developing countries. Benjamin F. Hobbs (1995) examined how environmental concerns, increased competition, and growing uncertainty have changed the needs of utility planners for optimization models and surveyed a range of models for electric utility resource planning that have developed in response to those needs. Swisher, J.N et al. (1997) assembled all necessary information addressing tools and methods for integrated resource planning to improve energy efficiency and protect the environment. Shrestha et al. (1998) developed the integrated resource planning (IRP) model to address the implications of a carbon tax and technological constraints in a developing country. Shrestha and Marpaung (1999) analyzed alternatives for reduction of greenhouse 
gases from Indonesian electric power generation by integrating supply- and demand-side options in an electric utility planning considering the effects of carbon tax. Shrestha and Marpaung (2002) examined the implications of $\mathrm{CO}_{2}$ emission targets in Indonesian power sector using the IRP analysis. Somporn, T., et al (2004) applied the IRP model to examine the effects of both supply and demand side options on the $\mathrm{CO}_{2}$ mitigation potential from the power sector in Thailand. Subhes C. B., et al (2004) examined the cogeneration potential of the sugar industry to meet the increasing electricity demand in Vietnam based on avoided cost ground under the IRP framework, Khanh $(2007 \mathrm{a}, \mathrm{b})$ estimated the potential of wind energy using a geographical information system assisted approach and used the MARKAL, a least cost model, to simulate the impacts of wind power generation and $\mathrm{CO}_{2} \underline{\text { emission constraints on the }}$ future choice of fuels and technologies in Vietnam's power sector. All of these studies suggest that integrating renewable energy sources in a cost-effective way is a necessary answer to the energy/environment dilemma.

This paper attempts to give new insights about what it is possible to do in terms of generating electricity and reducing carbon emissions in Vietnam. The originality of this study is to explore the potential of renewable energy sources for electricity generation in Vietnam. To the end, using the IRP model we analyze the optimized integration of a large array of grid-connected renewable energy technologies, i.e. hydro, geothermal, biomass, wind, solar,...etc in the power electric generation system to meet the challenges of soaring electricity demand, growing environmental concerns, energy pricing climax, and energy security over the period 2010-2030. This IRP analysis is performed for a comprehensive context of changes in market level of fossil fuels prices, evolution of renewable energy technological innovation, and constraints on fossil fuels supply.

The next section summarizes the development of Vietnam's power sector from 1995 to 2005 and makes projections out to 2030. It also summarizes quantitatively the national potential of renewable energy sources for electricity generation. Section 3 presents the IRP model and the two scenarios to be compared: with and without renewables. Results discussed in section 4 examine the extent to which 
renewables can substitute for coal in the optimal generation mix through 2030, and the economic and environmental benefits of such substitution. Section 5 presents a sensitivity analysis based on electricity demand forecast scenarios, the availability of fuels/electricity sources, trends of fossil fuel prices, and costs of renewable energy technologies. Some policy implications are then proposed for an electric power generation plan in Vietnam. Section 6 concludes.

\section{The power sector and renewables in Vietnam: status and perspectives}

Electricity generation, transmission and distribution in Vietnam are mostly provided by Electricity of Vietnam (EVN), a state-owned monopoly established in October 1994 under the Ministry of Industry. At the end of 2005, the total electricity generation capacity was $11,340 \mathrm{MW}$, of which Electricity of Vietnam facilities accounted for approximately 78\%. The remainder was owned by other local and foreign Independent Power Producers.

The current electricity generation system in Vietnam consists of thermal gas-based power plants (39\%), hydropower plants (37\%), and thermal coal; this last now accounts for approximately $16 \%$ of electricity generation, and it will play an increasingly important role in the medium and long term. Transmission and distribution loss in Vietnam remains high, even if it has been significantly reduced from $22 \%$ in 1995 to $12 \%$ in 2005 . EVN has developed a plan to reduce transmission and distribution losses to less than 8\% by 2025 (Electricity of Vietnam, 2006a, b).

The development of the electric power sector in Vietnam is managed using the Power Development Master Plan, which estimates the need for electricity and plans the overall development of the power sector during a 10-year period, taking into account the subsequent 10 -year period. The current Sixth Power Development Master Plan was approved by the Prime Minister in July 2007. It projects that an additional capacity of more than $10,000 \mathrm{MW}$ will be required between 2005 and 2010 to meet the rapidly growing demand for electricity services. Figure 1 maps the distribution of electricity generation sources in Vietnam planned for 2010. 
Figure 2 presents the historical and forecasted need for electricity energy in Vietnam since 1990, when the Vietnamese Government launched a comprehensive reform. This reform has helped to improve people's living conditions and has driven the development of the national economy. Gross domestic production (GDP) in Vietnam has experienced a rapid growth rate of $8.2 \%$ per annum during 19911995. The strong economic growth is the main reason that electricity demand has increased by $13.5 \%$ over the same period. Demand then grew faster, by $14 \%$, over the period $1995-2005$, together with economic development. The Sixth Master Plan was formulated based on scenarios for development of different economic sectors and regions and a comparative analysis using the three forecasting methods of multi-regression, elasticity and intensity. According to this Plan, the electricity demand is expected to increase by $15 \%$ per annum in the low demand scenario and by $18 \%$ per annum in the high demand scenario over the period of 2010-2030.

"Renewable Energy, a large potential in Vietnam wasted" is currently a popular theme in Vietnamese media. Table 1 shows that Vietnam has rich renewable energy sources that are not yet fully exploited. $\underline{\text { Renewable potentials are commonly classified in different categories of theoretical, technical, and }}$ economic potential. Theoretical potential is defined by the maximum available energy that could be exploited in a region without consideration of any restrictions. Technical potential is defined by the energy that could be yielded using existing technology and thus depends on the moment of assessment. Economic potential is defined by the energy that could be yielded using economically feasible installations. Infrastructure or technical constraints and economic aspects (costs of alternative competitive energy sources) determine the limits of the economic potential (Voivontas, D et al, 1998). Hydro energy: Vietnam has 2400 rivers with the length of $10 \mathrm{~km}$ or longer. The hydro energy economic potential is estimated at $84 \mathrm{TWh} / \mathrm{yr}$, which is more than the electricity consumption in 2005. Hydro pump storage energy: Vietnam's economic potential is over 10,000 MW of hydro pump capacity. These resources are mainly located in the northern and southern areas of the country. 
Geothermal energy: With more than 300 hot streams from $30^{\circ} \mathrm{C}$ to $148{ }^{\circ} \mathrm{C}$, Vietnam is preliminarily estimated to have 1,400 MW that could be developed for direct use and producing electricity. In which, $400 \mathrm{MW}$ geothermal capacity could be developed for producing electricity up to 2020 .

Biomass energy: Biomass resources that could be used for generating electricity include rice husk, paddy straw, bagasse (sugar cane, coffee husk, and coconut shell), and wood and plant residue with a potential of 1000-1600 MW.

Solar energy: Vietnam lies from $23^{\circ}$ to $8^{\circ}$ North latitude and has good constant solar sources. In the southern and central areas, solar radiation levels range from 4 to $5.9 \mathrm{kWh} / \mathrm{m}^{2} /$ day uniformly distributed throughout the year. The solar energy in the north estimated to vary from 2.4 to $5.6 \mathrm{kWh} / \mathrm{m}^{2} / \mathrm{day}$.

Wind energy: Vietnam has approximately $513 \mathrm{GW}$ of theoretical capacity. Excluding restrictions on the exploitation of the potential, $120.5 \mathrm{GW}$ of wind power capacity, about 10 times the peak load demand in 2005 is estimated economically feasible for producing electricity. Due to the intermittent nature of wind energy, crossing $20 \%$ wind generation capacity over the total generation system capacity installed is a realistically technical practice before 2020.

Here we examine the economic potential of renewables, assuming that no barriers to the adoption of these renewable energy technologies and that they are used optimally from a lowest-cost perspective. We then use the integrated resource planning (IRP) model to compare two optimized plans for expanding electricity generation in Vietnam, one with and the other without renewables. To the end, sensitivity analysis is performed to seek greater energy independence and energy security by integrating diverse energy sources and to response the questions of at what conditions would the renewables become cost-competitive with fossil options in Vietnam.

\section{The Integrated Resource Planning (IRP) model}

Most developing countries face the chronic problem of insufficient financial resources for developing their electric power sector because such development requires huge capital investments. Ineffective exploitation and use of limited domestic energy resources usually leads to electric power supply 
shortages, creating the need to import fuel or electricity, which puts a major drain on foreign exchange reserves. Moreover, climate change and public health problems can further complicate the development of the power sector in these countries. The United Nations Conference on Environment and Development agreed in June 1992 that all countries should adopt necessary adequate programs to restrain increases in greenhouse gas emissions. This restraint is an environmental hindrance to the development of the power sector in many developing countries.

To address these challenges, energy planners use optimization methods for electric utility resource planning, which is the selection of power generation and energy efficiency resources not only to meet the increasing need for electricity services with cost-effective reductions in the use of electricity but also lessen the impacts associated with electricity generation. Shrestha and Nguyen (2003) presents the integrated resource planning (IRP) model, which was developed in 1998 by the Energy Program of the School of Environment and Resources Development of the Asian Institute of Technology. It uses mixed-integer linear programming (MILP) to compute a lowest-cost electricity generation capacity expansion plan. The objective function of the IRP model is to compute the least cost combination of generation capacities of different generation sources, the level of end-use electrical appliances to be added (i.e. demand side), and the level of electricity generated by different plants subject to the following constraints:

(i) Demand constraint: The total power generation by all power plants (existing and future) and generation avoided by demand-side management options should not be less than the total projected power demand in all periods (blocks) ${ }^{1}$, seasons, and years of the planning horizon.

(ii) Plant availability constraint: The power generation of each plant is limited to the capacity and availability of the plant during each period of the day.

\footnotetext{
${ }^{1}$ The daily chronological load curve in the model is divided into several blocks (i.e. time intervals) in order to adequately reflect the effects of variations in power demand over various periods of a day
} 
(iii) Reliability constraint: The total power generation capacity of all the plants and generation capacity avoided by demand-side management options must not be less than the sum of the peak power demand and the reserve margin in each year of the planning horizon.

(iv)Annual energy constraint: A maximum limit is set on the energy generation at each plant based on its existing capacity, availability, and maintenance schedule.

(v) Hydro energy availability constraint: The total energy output of each hydro plant in each season should not exceed the plant's maximum available quantity of hydro energy.

(vi)Maximum potential capacity constraint: Total installed capacity of each type of power plant must not exceed the maximum allowable capacity of that plant type.

(vii)Minimum operation capacity constraint: All selected thermal generating units, depending on their characteristics (off-peak, intermediate, peak plants...etc) must be operated and dispatched to generate electricity energy production at a certain minimum business running capacity, at least.

(viii) Fuel or resource availability constraint: Energy generation from a plant cannot exceed the maximum available quantity of fuel supply resources.

(xi)External power availability constraint: Energy generation imported cannot exceed the maximum available quantity of external power generation resources.

(x)Demand side management constraint: The level of energy efficient device selected in a year must not exceed the maximum feasible level of such device in the year.

In the IRP model, the electricity price in terms of average incremental cost (AIC) and long run average cost (LRAC) does not play any driven role to compute the optimal solution. These costs are calculated, based on the optimal solution computed for the electricity generation capacity expansion plan using the following formulas:

$$
A I C=\left(T C-C_{1}-\sum_{i=1}^{T} V C_{1} /(1+r)^{i}\right) /\left(\sum_{i=2}^{T}\left(E_{i}-E_{1}\right) /(1+r)^{i}\right)
$$




$$
L R A C=T C /\left(\sum_{i=1}^{T} E_{i} /(1+r)^{i}\right)
$$

where $T C=$ present value of total cost including capital, fuel, operation and maintenance costs; $C_{1}=$ present value of capital cost in year $1 ; V C_{1}=$ total fuel, operation and maintenance, and demand-side management costs in year $1 ; E_{1}$ and $E_{i}=$ electricity generation in year 1 and year $i ; r=$ discount rate; and $T=$ planning horizon .

We consider 14 alternative generation technologies and 10 kinds of fuels. Table 2 summarizes the technical, economic, and environmental characteristics of these generation technologies. The renewable energy generation technologies (RET) considered are: small and mini hydro, geothermal, wind turbine, solar grid connected, biomass-based integrated gasification combined cycle, and biomass direct combustion. Table 3 displays the fuels prices used in the model. Price escalation is defined as the total annual rate of increase in a cost, including the effects of both inflation and real escalation. We assumed that the fuels prices could increase 1-2 percent per year based on the price estimation in 2005 of Institute of Energy, 2006c. They are relatively moderate compared to the market levels observed in recent years. Thus, a sensitivity analysis of the study is performed to reflect more realistically the current market levels observed.

In this study, the economic potential of renewable energy and its implications for the development of electric power generation in Vietnam are analyzed by comparing a model run without renewables against a model run with renewables. The two scenarios will be named "B1" and "B2". The B1 scenario assumes that the power sector in Vietnam for a period of 2010-2030 will not develop any renewable energy sources, except for large hydro and hydro pump storage. The B2 scenario assumes that during the same period, all of the economically possible RETs mentioned above will be considered for sustainable development of electric power generation in Vietnam. In all other respects, the scenarios are identical. Both scenarios assume the adoption of highly energy-efficient thermal technologies such as supercritical and IGCC coal-fired plants, NGCC gas-fired plants and they assume that there are no 
direct climate change policy interventions. The same average predicted load demand, transmission and distribution losses, and electricity consumed during certain periods (see Table 4) are applied to both scenarios. Furthermore, both assume that nuclear energy and demand-side management are not used.

To meet the rapid increase in electricity demand forecast for 2010-2030, Vietnamese organizations are considering different economic alternatives for expanding the electricity generation system. Fuels considered economically viable for producing electricity are domestic fossil fuel resources and imports, including imported electricity. The availability of domestic fuels supply is based on exploiting estimation scenarios of natural gas and coal mining industries locally. The possibilities for importing fuel or electricity sources have been estimated depending on their availability and national financial resources. The electricity import is mainly from hydro sources via ASEAN power interconnection system projects that have been concurred or negotiating with neighbor countries such as China, Lao, and Cambodia. The success of these projects depends on involved countries' economic development, impacts of international market pricing level, national strategy on bilateral and multilateral cooperation, etc... The Vietnamese Government agencies, however, have also carried out an overall assessment of the feasibility of importing electricity and its purchasing prices from these projects (Institute of Energy, 2006c). In the model, the electricity imports are simulated by different hydro generation sources with purchasing electricity prices varied from 4.3-4.9 \$cent/kWh. Table 5 indicates the maximum quantity of domestic fuels supply and imports (fuels/electricity) for baseline scenarios and sensitivity analysis.

The scenarios applied in this study coincide with the baseline forecast and estimates from official Vietnamese Government agencies. These predictions, however, include very few renewables.

\section{Results}

Since IRP is a bottom-up optimization model, optimizing over a broader technology portfolio can improve results. Thus, it is no surprise that the B2 run (with renewables) performs better economically than the B1 run (without renewables). What is more interesting, perhaps, are the quantitative differences between the two scenarios, which are summarized in Tables 6 and 7 and discussed in more 
detail below. We examine in turn the implications for electricity planning, the benefits of using renewables from the perspective of domestic energy security, the cost improvements, and the environmental benefits.

Overall, IRP simulation suggests that $4.4 \mathrm{GW}$ could be obtained from renewable energy sources in a cost-effective manner for the production of electricity in Vietnam. Small hydro and geothermal energy account for $45.5 \%$ and $31.8 \%$ of this quantity, respectively. The rest comes from biomass energy (bagasse, rice husk, and paddy straw).

Implications for Electricity Planning: How could the combination of diversified energy sources, including unconventional energy sources, enable the expansion of electric power generation in Vietnam? IRP results indicate how the addition of electricity-generating capacity and the diversification of electricity sources could be technologically achieved during the specified period. Compared to the B1 scenario, the more cost-effective combination of energy resources in the B2 scenario reduces the total amount of electricity generated by conventional thermal plants. The IRP simulation suggests that electricity generation based on coal-fired plants can be reduced from $43.6 \%$ to $39 \%$, and gas-fired plants reduced from $32.4 \%$ to $32.1 \%$. This change is primarily due to the fact that RETs can compete more effectively against traditional electricity sources in terms of cost. While the electricity generation based oil-fired plants would be kept unchanged in both scenarios B1 and B2. This is because no new oil-fired plants would be cost-effective selected and all the existing ones are continuously operated as reserve or peak generating units in the system to provide with a certain level of electricity generation in both scenarios.

Introducing RETs into the electric power generation system could help the country to avoid installing 4.4 GW in fossil fuel generating capacity. This is because RETs offer the supply-side option of unit sizes of various capacities with low or zero fuel cost. Both advantages could make RETs more costeffective than other technologies in responding to variations in demand for electric power at different times. It is important to note, however, that the B2 scenario requires an increase of $232 \mathrm{MW}$ in 
additional generation capacity. This implies some generating plants that operate less efficiently in the B1 scenario would, in the B2 case, need to be relied upon less for electricity generation or be operated at a certain minimum level of generation as part of a "capacity reserve margin" or be replaced completely by higher-generating facilities.

As a result of IRP, compounding renewable energy sources with conventional sources could help the country increase total average thermal efficiency from $46.7 \%$ in the B1 scenario to $47.2 \%$ in the B2 scenario, as well as decrease the weighted average capacity factor ${ }^{2}$ from $64.7 \%$ in the B1 scenario to $64.4 \%$ in the B2 scenario. This shows that generation units that are more energy-efficient can be more effectively utilized and some generation units that are less efficient can be relied upon less or even replaced completely, and more geothermal grid-connected generation units with very high thermal energy efficiency could help significantly improve the overall average thermal system efficiency.

The total electricity generation as modeled here, which must be equal to or larger than total demand in equilibrium, is reduced by $19.5 \mathrm{TWh}$ in the B2 scenario compared to the B1 scenario during the same outlook period. This is because in the IRP model all selected thermal generating plants (existing and future) are simulated with different minimum operating capacities depending on their characteristics (technologies, fuels, capacity, and off-peak, intermediate, peak operation modes, ...etc). This simulation implies that whenever a thermal power plant is constructed, it must be dispatched to generate electricity at a certain minimum business running capacity, at least. On this simple ground, when some generating units on reserve with less efficiency but larger minimum operation capacities in $\underline{\text { scenario B1 are, in scenario B2, replaced by higher efficient units with smaller minimum operation }}$ capacities, the accumulated minimum electricity generation from those on reserve in scenario B2 could

\footnotetext{
${ }^{2}$ Capacity factor of a power plant is the ratio of its actual total electricity generation during a period to the maximum potential electricity generation if it had operated at full installed capacity during same period. The weighted average capacity factor is calculated from annual capacity factors with weights being the annual shares in cumulative electricity generation during the entire planning horizon.
} 
be reduced. This results in reduction in the total electricity generation in scenario B2 accordingly, compared to scenario B1 over the whole planning period.

The second question of how the development of electric power generation integrated with such RETs can maintain the same quality level of electricity services compared to the B1 scenario is also examined. As an answer to this question, Table 7 shows an appreciable decrease in the weighted average loss of load probability (LOLP) $)^{3}$ from $0.05 \%$ in the B1 scenario to $0.01 \%$ in the $\mathrm{B} 2$ scenario and a significant reduction in total expected energy not served (EENS) ${ }^{4}$ from 57.7 GWh in the B1 scenario to $8.5 \mathrm{GWh}$ in the $\mathrm{B} 2$ scenario during the specified planning period. The finding suggests that the more continuous supply of electricity can benefit consumers. This is because reserve capacity in the B2 scenario increases as some existing plants would become less intensively used and some others would become redundant generation units. In addition, RET units are simulated with higher availability factors and lower unit forced outage rates that would all improve the LOLP and EENS.

Implications for Natural Energy Resource Conservation and Energy Security: How could more efficient use of more diverse energy resources in Vietnam, including more non-conventional sources, help the country conserve domestic energy sources and slow the drain on scarce foreign exchange reserves due to fossil fuel importing?

Figure 3 and Table 7 suggest that cost-effective renewable sources could substitute to a relatively small extent for domestic coal and natural gas. The country could save approximately 141.4 million tons of domestic coal and 1.53 billion $\mathrm{m}^{3}$ of domestic gas for producing electricity during the specified period. Furthermore, Figure 4 indicates that the country could slightly reduce its imports: the demand for imported resources in the B2 scenario is only 304 million tons of coal, 75 billion $\mathrm{m}^{3}$ of natural gas, and

\footnotetext{
${ }^{3}$ Loss of load probability (LOLP) is the proportion of time when the available generation is expected to be unable to meet the system load. Weighted average LOLP is calculated from annual LOLP figures with weights being the annual shares in cumulative electricity generation during the entire planning horizon.

${ }^{4}$ Expected energy not served (EENS) is the expected amount of energy not supplied during a period due to insufficient capacity.
} 
377 TWh; compared to the B2 import demand of 311 million tons of coal, 78 billion $\mathrm{m}^{3}$ of natural gas, and 385.6 TWh. This corresponds to savings of 1.34 billion US\$ in fuel/electricity imports.

These results were obtained assuming that the prices for domestic and imported fossil fuels are moderate and have annual inflation rate relatively slowly compared to the market levels observed in recent years. Prices in 2008, for example, are higher than those assumed in the study: the market price of gas and coal is $20-50 \%$ higher, the price of fuel oil (DO, FO) is $70-85 \%$ higher, and of the annual inflation rate of fuel prices rose from $2.3 \%$ to $3 \%$ per year (World Energy Outlook, IEA 2006). This alone argues convincingly for the need to seek greater energy independence by integrating diverse energy sources, including renewable energy sources, for producing electricity in Vietnam.

Cost and Pricing: How cost-effective would the combination of diverse energy sources be for producing electricity in Vietnam?

Table 7 suggests that a reduction of $2.6 \%$ (1.3 billion US\$) in the total discounted cost of electric power generation plan could be gained by optimizing the inclusion of renewables in the mix. Figure 5 and Table 7 compare the B1 and B2 scenarios in terms of annual fuel and variable cost. Since fuel and variable cost account for $60-75 \%$ of the cost of electricity production, the lower fuel and variable costs in the B2 scenario (1.1 billion US\$ lower compared to the B1 scenario) could lead to lower production costs. In addition, lower capital and fixed operation and maintenance (O\&M) costs in the B2 scenario imply that some RETs in Vietnam, such as small hydro, geothermal, and biomass (except wood) could become cost-effective enough to compete against conventional sources.

Integrating RETs in the development of electric power generation could not only help the country reduce the financial effect of increased demand for electricity, but it could also reduce electricity pricing in Vietnam by $0.03 \$$ cent $/ \mathrm{kWh}$, in terms of average incremental cost (AIC), for the period of 2010-2030.

Environmental Implications: To what extent could renewables reduce the health and environmental effects of meeting the nation's increased demand for electricity? The IRP permits analysis of the 
mitigation potential of renewables with respect to emission of $\mathrm{CO}_{2}$ and other harmful substances in the power sector in Vietnam.

Table 7 shows that the total cumulative $\mathrm{CO}_{2}$ emission released in the $\mathrm{B} 2$ scenario is significantly reduced by $8 \%$ over $3,825 \mathrm{Mt}$ emitted in the B1 scenario for the period 2010-2030. This is an average reduction of $15 \mathrm{Mt}$ of $\mathrm{CO}_{2}$ per year during 2010-2030, which compares favorably to the estimated $36 \mathrm{Mt}$ of total $\mathrm{CO}_{2}$ emission emitted from Vietnam's electricity generation industry in 2006 (Nguyen and Tran 2005). Typically for this kind of bottom-up model, the abatement cost is negative, since the model finds an optimal solution that involves a broader array of technologies.

In addition to mitigating global emission, the country could also avoid $3 \%$ of total $\mathrm{SO}_{2}$ and $4 \%$ of total $\mathrm{NO}_{\mathrm{X}}$ emissions emitted during the same period. This is an average reduction of $3.9 \mathrm{Kt}$ of $\mathrm{SO}_{2}$ and 11.8 Kt of $\mathrm{NO}_{\mathrm{X}}$ per year during 2010-2030, which compares favorably to the estimated $128.2 \mathrm{Kt}$ of total $\mathrm{SO}_{2}$ and $102 \mathrm{Kt}$ of total $\mathrm{NO}_{\mathrm{X}}$ emitted by the sector in Vietnam in 2006 (Nguyen and Tran 2005).

In this study, the optimization procedure did not take into account the environmental or health costs of energy sources. Including these costs would reduce the use of conventional thermal power plants, especially coal-fired plants. At the social optimal, emissions of $\mathrm{CO}_{2}$ and other harmful substances by the electricity-generating industry in Vietnam would be reduced accordingly.

\section{Sensitivity analysis and discussion}

The IRP simulation suggests that some power-generating plants based on renewable technologies such as solar, wind, and biomass wood are still not cost-effective, mainly because of the high cost of these technologies. However, these costs are expected to fall over time due to technological innovation.

In this study, some sensitivity analysis case studies (referred to as SA1 through SA7) are performed based on estimates of different parameters: quantities of fuel/electricity imported and domestic fuels supply during the period 2020-2030, which is based on the country's policy and availability of fuel/electricity sources (Table 5); low/high load demand forecasts, which reflect greater or smaller prospects for economic development during 2020-2030 (Table 4); changes in fuel prices based on 
market levels observed in recent years and World Energy Outlook, IEA 2006 (Table 3); and reductions in the renewable energy generation technologies costs based technological innovation evolution (Erik Ahlgren et al, 2007). Some policy implications will then be discussed and proposed for the electric power generation plan in Vietnam.

The first part of this section determines the answer to the question of at what conditions would the renewables become cost-effective with fossil options in Vietnam, and how much these could be costeffectively generated. Table 8 shows that all assumed potential of small hydro, geothermal, and biomass technologies, except for wood energy could be economically exploited in a cost-effective manner in the scenarios B2. Among these RETs, small hydro has the biggest potential for producing electricity. In the B2 scenario, small hydro and geothermal could cost-effectively generate $146.5 \mathrm{TWh}$ and 124.3 TWh, respectively, during 2010-2030. Biomass energy (other than from wood) could costeffectively generate of the remaining $26.8 \%$ of the total 370 TWh generated by RETs during this period. In all scenarios of sensitivity analysis, the total electricity generated by geothermal (1400 MW) and biomass (1000 MW) over 2010-2030 would not exceed that in scenario B2. This is because the maximum potential for these two renewables to generate electricity in a cost-effective manner has been achieved. In contrast to the other RETs examined in this study, wind power, wood energy, mini hydro, and solar energies could not be cost-competitive with conventional energy sources to produce electricity at their technology costs and fossil fuel prices assumed in the B2 scenario. The following discusses what would be required to make them cost-effectively competitive.

The higher prices of fossil fuels in scenarios SA5, SA6, and SA7 could make the additional small hydro capacity potential (300 MW) become competitive in terms of cost-effectiveness, and in this case small hydro could generate a maximum of $163 \mathrm{TWh}$ in a cost-effective manner. IRP simulation also suggests that mini hydro energy potential of $100 \mathrm{MW}$ could become cost-effective, and that it could cost-effectively generate $4.7 \mathrm{GWh}$ in the case of high fuel prices. In the combined case of high fuel prices and a forecast of high load demand, mini hydro could generate up to $4.9 \mathrm{GWh}$. 
Neither wind power nor wood biomass could become cost-effective, either in the scenario of predicted high load demand or the scenario of increased fuel prices. However, if the cost of power generation technology based on wood energy fell to approximately $1500 \mathrm{US} \$ / \mathrm{kW}$ (100 US\$/kW lower than in the B2 scenario), it would become cost-competitive in the case of high fuel prices. Table 8 suggests that in the SA7 scenario, wood energy could provide $100 \mathrm{MW}$ and 10.6 TWh effectively during the specified period. This key finding argues for investment in wood plantation-based power-generating plants in the Vietnamese power sector.

In the scenario SA6, wind power is found to be cost-effective if its technology cost falls to approximately $900 \mathrm{US} \$ / \mathrm{kW}$ (100 US\$/kW lower than the baseline scenario) in the context of high fuel prices. Wind power capacity of $4622 \mathrm{MW}$ could be installed by 2030 , with a total of $240.2 \mathrm{TWh}$ generated during the period 2010-2030. This implies the possibility of integrating wind power into the Vietnamese power sector in the form of Clean Development Mechanism (CDM)-funded projects.

In contrast to the other RETs, power generation technology based on solar energy was not costeffective in any of case studies even at a promising technological innovation cost level of $1300 \mathrm{US} \$ \mathrm{~kW}$. This simulation implies that solar energy gird-connected technology would be still expensive for cost-competitive with others in Vietnam's power sector for the next 20 years, at least.

The second part of this section focuses on argument for seeking greater energy independence and energy security by integrating diverse energy sources for generating electricity in Vietnam under hypotheses of market changes in fuels prices and insufficient fossil fuels supply. With this objective in mind, the sensitivity analysis is commenced with the SA8 hypothesis, in which high fossil fuels prices, constraints on imported natural gas, coal fuels and electricity, and no constraint on domestic coal fuel are coherently examined. As SA9 through SA11 hypothesis, different quantitative constraints on domestic coal fuel used for producing electricity are additionally considered. As modeled here, when additional constraints on imports (gas and electricity), and high fossil prices introduced in the SA8 hypothesis, reductions in imports capacities would be trade-off substituted by 
capacity additions of domestic coal, gas, large hydro, and renewables (small and mini hydro). IRP simulation indicates that the total $4 \mathrm{GW}$ capacity potential (equals to $205 \mathrm{TWh}$ in electricity generated over 2010-2030) of small and mini hydro would be mostly economically dispatched to generate electricity over the specified period in this hypothesis. Wind power and wood biomass are still not costeffective dispatched in this SA8 hypothesis because no-constraint on domestic coal supply in this hypothesis allows the power generation system based low-cost coal fuel for producing electricity over the outlook period. However, when coherent constraints on domestic coal fuel supply are introduced additionally as SA9 through SA11 hypothesis, the power generation system would be switched to $\underline{\text { capacity additions different from domestic coal and electricity import. This switch causes a strong }}$ growth in usage of large hydro and renewables for generating electricity. Table 8 suggests that both wood biomass and wind power would become cost-effective generated in the SA9 hypothesis and the cost-effectiveness in generating electricity of both renewables would be growing at higher constraints on fossil fuels supply as the SA10 through SA11 hypothesis.

Given the plausible conditions in SA11 hypothesis, the potential of $20 \mathrm{GW}$ of wind power capacity (equals to $162 \mathrm{TWh}$ in electricity generated over 2010-2030) along with large hydro (18 GW in capacity equals to $1316 \mathrm{TWh}$ ) and small/mini hydro (4 GW in capacity equals to $205 \mathrm{TWh}$ ) could help to seek greater energy independence and security. It notes here even only $4.6 \mathrm{GW}$ of wind capacity could be cost-competitive generated in the SA6 scenario, the total electricity generation of wind power is much larger than those are in the SA9-SA11 scenarios, where mostly its potential of $20 \mathrm{GW}$ costeffective exploited. This is because wind power in scenario SA6 would become more cost-competitive with fossil options for generating electricity as result of its technological innovation rather than it would be cost-effective selected to trade-off with coal capacities in the SA9-SA11 scenarios as peak generating units or generating units on reserve, which could be operating to generate a certain amount of electricity energy. This gives implications that wind power could play an even more important function to the fuel-mix generation if policy changes such as carbon tax, carbon emissions constraints, 
or externalities costs of fossil fuels are introduced in the power sector. And integrating the bursting potential of wind power into electricity generation portfolio should not be forgotten for future development in Vietnam.

Another note is taken from modeled result is that the potential of large hydro energy could be more economically developed for generating electricity in the context of price effects or insufficient fossil fuels supply.

\section{Concluding remarks}

This paper examines the potential of renewable energy sources for forming part of the national plan to generate electric power in Vietnam. The candidate grid-connected generation technologies include small hydro, mini hydro, geothermal, solar, wind turbine, integrated gasification cycle based on biomass (rice husk, paddy straw, wood residue), and direct combustion technologies based on biomass (bagasse). Using the Integrated Resource Planning model, the study examines and compares the costeffectiveness of all resource alternatives on the supply side, taking into account their different economic, environmental, and reliability characteristics.

Compared to the paper results of Khanh (2007b), this paper's simulation result gives the same suggestions that regardless of whether they include RETs, the power sector in Vietnam will rely primarily on fossil fuels after 2015. Coal is expected to dominate the energy mix. Large quantities of $\underline{\mathrm{CO}_{2}} \underline{2}$ will be emitted into the atmosphere from electricity generation. The soaring demand for electricity services over 2010-2030 may exceed the domestic fuels supply sources for generating electricity in Vietnam. The country, thus, need to import electricity energy as soon as 2010 , coal and natural gas since 2015 and 2016 respectively.

In fact, this study finds that without renewables, electricity energy generation from fossil fuels may account for $76.34 \%$ of the total production of 7389.6 TWh over the specified period. In this case, coal would account for $43.6 \%$ of the total production, while hydro would account for only $18.4 \%$. Fossil fuel sources are the primary contributors to the increasing share of $\mathrm{CO}_{2}$ emissions due to the power 
sector. The increase would be from $60.7 \mathrm{Mt}$ in 2010 to $352.3 \mathrm{Mt}$ in 2030 , equals to a growth rate of $23 \%$ per year that will total $3825.3 \mathrm{Mt}$ for the period $2010-2030$. There is, thus, a need for proper measures and adaptable policies to ameliorate environmental impacts of the power sector development. Fully integrating renewable energy technologies in the generation portfolio may bring significant cobenefits to the country.

At a moderate assumption level of fossil fuels prices, $4.4 \mathrm{GW}$ of the renewable energy capacity potentially available could now become cost-effective for replacing conventional fuel generating capacities to produce electricity in Vietnam. Of the capacities that could operate cost-effective, small hydro energy accounts for $45.5 \%$, geothermal accounts for $31.8 \%$, and biomass energy (bagasse, rice husk, and paddy straw) accounts for the remaining $22.7 \%$. With the contribution of renewables capacities, the share of electricity generation provided by coal fuel could be reduced by $5 \%$. This would reduce the total cumulative $\mathrm{CO}_{2}, \mathrm{SO}_{2}$, and $\mathrm{NO}_{2}$ emissions by $8.2 \%, 3 \%$, and $4 \%$ respectively during the period 2010-2030. The study finds that the introduction of renewables could contribute to an increase in average thermal efficiency from $46.7 \%$ to $47.2 \%$ and a decrease in average loss of load probability from $0.05 \%$ to $0.01 \%$ that leads to greater reliability and improvements in electricity supply services. In terms of energy resource conservation and energy security, using renewables could potentially reduce the use of domestic coal and natural gas for producing electricity by 141.4 million tons and 1.53 billion $\mathrm{m}^{3}$, respectively for the period 2010-2030. The country would need to import only $\underline{303.8 \text { million tons of coal and } 75.5 \text { billion } \mathrm{m}^{3} \text { of natural gas and } 377 \text { TWh during 2010-2030, instead of }}$ $\underline{311.2 \text { million tons of coal, } 78.4 \text { billion } \mathrm{m}^{\frac{3}{3}} \text { of natural gas, and } 386 \mathrm{TWh} \text { that must be imported over the }}$ same period in the scenario of none using renewables. In other words, the country could avoid spending 1.34 billion US\$ to import fuel and electricity to meet energy demand during this period. In term of coat and pricing implication, integrating a broader panel of diverse renewable technology options in the electricity generation portfolio could potentially reduce the AIC and LRAC of electricity generation by

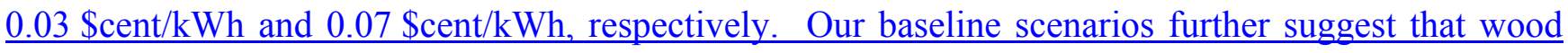


biomass, wind power, and solar with their current technological innovations are not yet cost-effective grid-connected generation sources at the moderate level of fossil fuels prices.

At a higher level of fossil fuels prices assumed, which reflects more realistically the current market pricing levels observed, mini hydro with limited capacity of $100 \mathrm{MW}$ and additional small hydro capacity of $330 \mathrm{MW}$ would be added to cost-effective generation sources. Wind power and wood biomass could not cost-competitive enter the grid-connected generation portfolio. Both, however, will become so as a result of future changes in the market, in the technologies themselves, or insufficient fossil fuel supply.

Consolidating the prospects of wind power industry evolution in Vietnam as argued in Khanh (2007b), the study demonstrates that wind power could be cost-competitive compared to other conventional energy generation sources in the context of high but plausible fossil fuel prices, if its cost falls to approximately $900 \mathrm{US} \$ \mathrm{~kW}$ or if the fossil fuel supply from both import and domestic sources is constrained to the supply level examined as SA9 through SA11 hypothesis. These conditions are not irrational and could be approached realistically. Thus, more attention should be given to the opportunities that this abundant natural energy source offers for sustainable development.

Likewise, power generation technology based on wood energy could become cost-effective in meeting the challenge of increasing global demand and shrinking fossil fuel supply, as long as its cost falls around $1500 \mathrm{US} \$ / \mathrm{kW}$ or if the fossil fuel supply from both import and domestic sources is constrained to the supply level examined as SA9 through SA11 hypothesis. Given that these conditions are not implausible, the potential for power generation based on wood plantations in Vietnam merits consideration.

In contrast to the other RETs, solar grid-connected generation technology could be still not costcompetitive with fossil options at its technological innovation prospects by 2030 in the IRP simulation. The simulated result, however, does not decline the important role of this renewable option in connecting electricity to people, who are living in rural communities or island areas (Vietnam has more 
than $70 \%$ of populations living in remote areas) in the forms of off-grid generation system for village facilities, household-sized generation, or energy centers for recharging batteries, ...etc.

Among renewables potentials in Vietnam, hydro energy (small and mini) accounts for the largest portion to produce electricity in baseline analysis scenarios as well as in sensitivity analysis scenarios. The electricity production of small and mini hydro energy would be increasingly exploited up to its maximum potential of $4 \mathrm{GW}$ to meet the requirement of energy independence and energy security over the specified period.

Though large hydro energy source was supposition-ally considered as none renewable energy option in the analysis, the IRP result also notices us how important and how much could this renewable option remain the function in the Vietnamese electricity generation system under price effects and insufficient fuels supply conditions.

Above, we explored the economic potential of renewables, which is optimally utilized from a least cost perspective with no barriers to the penetration of these grid-connected renewable energy technologies. $\underline{\text { IRP results suggest that the country's available renewable energy sources could potentially contribute }}$ to satisfy the soaring electricity demand, diminish climate change globally and environmental effects locally, and enhance energy independence and security over 2010-2030. However, all these natural endowments remain successfully unexploited in practice due to the existence of the barriers:

Financial and Infrastructural barriers: As the national energy portfolio is continuously dominated by fossil fuels, under the existing market conditions the negative externalities of fossil fuels are not yet incorporated in electricity prices. EVN, the single-buyer of electricity, is not strategically obligatory to deal renewable energy projects, with pricing reflective of clean energy's extra benefits different from fossil fuel projects. Specific renewable energy costs, thus, are still above conventional energy prices. Furthermore, there is a lack of commercial business and infrastructure to provide renewable electricity generation equipment and services, and a limited access to finance for customers, businesses and project developers. 
Information, Capacity and Technical barriers: There is insufficient awareness/information on renewable technologies and data on the national potential of renewable energy sources. Furthermore, inadequate investment for research and development (R\&D) leads to unreliable national estimates of renewable energy sources and their technological development, and makes it difficulty for planning programs. Moreover, lacks of access to technology, skilled manpower, training facilities and R\&D facilities are so far hindering the promotion of renewable energy technologies in Vietnam.

Institutional and Legislative barriers: Insufficient co-ordinations and multiplicity bodies within the Government authorizations responsible for the deployment of renewable energy usage has been described as a major barrier to the successful adoption of these technologies. Specially, the current policy and regulatory framework for promoting the usage of renewable energy is inadequate to drive its development. Unless this barrier is removed, little can be expected in the direction of scaling up the renewable energy industry in Vietnam.

This paper focuses on the role of renewables for grid-connected power generation in Vietnam, it is not superfluous, however, to address that they may play an even larger role in off-gird electrification in remote areas. This is because Vietnam has more than $70 \%$ of populations living in these areas, where connecting people to the grid would be too costly, complicated or impossible. Over the last several decades, Vietnamese Government has extended enormous endeavors to bring electricity to these. At the end of $2005,88 \%$ of households or $95 \%$ of communes had access to electricity. According to the Government's rural electrification plan for the period 2001-2010, the remaining 400 communes containing 2 million households, which are un-reached by grid-extension will be supplied with electricity energy with off-grid connected renewable energy options such as mini and micro hydro, solar photovoltaic, and wind generator in forms of standalone and household-sized (Electricity of Vietnam, 2006a). Despite decentralized electrification takes such a large role for socio-economic development (i.e. reducing energy and capacity losses, avoiding the need for high cost utility generation, energy sources unlimited and free cost fuel usage, reducing emissions of air pollutants, 
offering more employment,...etc), connecting remote people to electricity has been hardly executed efficiently and encountering many similar barriers such as institutional and political, financial, information barriers, ...etc.

Conclusively, this study allows to give a more realistic overview and more reliable assessment of economical potential of the renewable energy sources for producing electricity as well as to draw out the future prospects evolution of the electric power generation industry in Vietnam. The key message gives that the country's renewable energy sources could potentially orient the power sector to greater opportunities for sustainable development if one realizes the usage of renewables is a necessary answer. And to access these opportunities, there is necessarily a demand for correct measures and better, adaptable policies that allow an economically and environmentally efficient exploitation of these natural endowed rich energy sources.

\section{Acknowledgements}

We thank Professor Ram M. Shrestha of the Energy Program of Institute of Technology in Bangkok, Thailand for his valuable advice on how to develop this work. All errors and opinions remain ours. This work has been implemented at the Centre International de Recherche sur l'Environnement et le Développement (CIRED, France) under a research grant for a Ph.D. program offered by the Centre National de la Recherche Scientifique (CNRS) of France.

\section{Bibliography}

BCSE (2005). Renewable Energy in Asia-Vietnam Report. Australian Business Council for Sustainable Energy, August 2005.

Benjamin, F. Hobbs (1995). "Optimization methods foe electric utility resource planning." European Journal of Operation Research.Vol83:1-20.

Chattopadhyay, D (1994). "System approach to emission reduction from a power system in India." Energy Sources, page 425-438.

Electricity of Vietnam (2006a). Planning Reports. Hanoi, Vietnam 
Electricity of Vietnam (2006b). Summary report of fuel prices and generation technologies in Vietnam power sector, Power Engineering and Construction Company No\#2.

Electricity of Vietnam (2006c). Brief introduction of electricity sector in Vietnam. A presentation performed by Dr. Lam Du Son, Vice president of EVN, at Asia Energy Conference 2006.

Enerteam (2001). Identification of Biomass Energy Projects in South East Asia (Cambodia, Laos, Vietnam). COGEN Report, AIT, Bangkok, Thailand.

Erik Ahlgren and Anjana, D., (2007). "Europe, South-East Asian Energy Modeling and Policy Programme.” ESMOPO project Report.

Fernando, C.S., Kleindorfer, P.R., Munasinghe, M (1994). "Integrated Resource Planning with Environmental Costs in Developing Countries.” Energy Journal. Vol15:93-121.

Hannele Holttinen et al (2006). "Design and Operation of Power Systems with Large Amounts of Wind Power, first results of IEA collaboration". Global Wind Power Conference September 1821, 2006, Adelaide, Australia.

Hoang Huu Quy (1998). “Overview of the Geothermal Potential of Vietnam.” Geothermics, 27(1): 109 $-115$.

Hoang Huu Quy and Ho Huu Hieu (2000). “Assessing the Geothermal Potential of Moduc Area Quang Ngai Province, Central Vietnam.” Proceedings of World Geothermal Congress 2000 Tohoku, Japan Institute of Energy (2006a). Biomass Energy Project in Vietnam. Working Report prepared by PREGA National Technical Experts from Institute of Energy, Hanoi, Vietnam.

Institute of Energy (2006b). The Sixth Master Plan on Electric Power Sector Development. Institute of Energy (2006c). The Pre-Feasibility Study on Nuclear Power Plant in Vietnam. Institute of Energy (2006d). Database of Electricity Forecasting model Simple_E, Working Database System, Energy Economics and Forecasting Department.

Khanh, Q. Nguyen (2007a). "Wind energy in Vietnam: Resource assessment, development status and future implications.” Energy Policy 35 (2007): 1405 - 1413. 
Khanh, Q. Nguyen (2007b). "Impacts of wind power generation and $\mathrm{CO}_{2}$ emission constraints on the future choice of fuels and technologies in the power sector of Vietnam.” Energy Policy 35 (2007): 2305 -2312 .

Nguyen Khac, N. (2007). "Research working papers on Vietnam Power Sector Development." URL: http://www.tailieu.tapchithoidai.org, accessed 11.12.2007”.

Nguyen, L.T, and Q.C. Tran (2004). "Potential Distributed Power Generation from Biomass Residues in Vietnam - Status and Prospect”. Electricity Supply Industry in Transition: Issues and Prospect for Asia.

Nguyen, T. N, and C. T. Tran (2005). "Strategies for Promotion of Energy Efficient and Cleaner Technologies in the Power Sector." National Reports (issue 1\&2) submitted to the Asian Regional Research Program in Energy Environment and Climate, Phase III.

PREGA (2004). Promotion of Renewable Energy, Energy Efficiency and Greenhouse Gas AbatementViet Nam country Report.

Shrestha, R. M. and C. O. P. Marpaung (1999). "Supply- and Demand-Side Effects of Carbon Tax in the Power Sector: An Integrated Resource Planning Analysis.” Energy Policy, Vol 27:185-194.

Shrestha, R. M., Shrestha, R, and S. C. Bhattacharya (1998). "Environmental and Electricity Planning Implications of Carbon Tax and Technological Constraints in a Developing Country.” Energy Policy, 26 (3): 527-533.

Shrestha, R.M, and C.O.P. Marpaung (2002). "Supply and Demand Side effects of Power Sector Planning with $\mathrm{CO}_{2}$ Mitigation Constraints in a Developing Country.” Energy, Vol27, page 271-286.

Shrestha, R.M. and T. N. Nguyen (2003). “The Integrated Resource Planning (IRP) Model, An User's Guide.” Working Paper, Energy Program, AIT, Bangkok, Thailand.

Somporn, T., Bundit, L., Ram M. Shrestha (2004). “ $\mathrm{CO}_{2}$ mitigation and power generation implications of clean supplyside and demand-side technologies in Thailand.” Energy Policy. Vol32:83-90. 
Subhes C. B., and Dang N. Q. Thang (2004)." Economic Buy-Back Rates for electricity from Cogeneration: Case of Sugar Industry in Vietnam.” Energy. Vol29:1039-1051.

Swisher, J.N., Gilberto M.J., and Robert Y. R. (1997). “Tools and Methods for Integrated Resource Planning.” UNEP Collaborating Centre on Energy and Environment.

TrueWind Solutions, LLC Albany New York (2001). Wind Energy Resource Atlas of Southeast Asia. Technical Report, the World Bank Asia Alternative Energy Program.

USAID (2007). From ideas to action: clean energy solutions for Asia to address climate change. Vietnam country report. United States Agency for International Development.

Voivontas, D., D. Assimacopoulos., A. Mourelatos (1998).” Evaluation of Renewable Energy Potential using a GIS Decision Support System.” Renewable Energy, Vol13:333-344. 


\section{Figures and Tables}

Table 1: Assessment of the potential for renewable energies to supply electricity in Vietnam

\begin{tabular}{|c|c|c|c|c|}
\hline Energy resources & $\begin{array}{c}\text { Economical } \\
\text { potential }\end{array}$ & $\begin{array}{c}\text { Current development in } \\
2005\end{array}$ & $\begin{array}{l}\text { Future development planned up } \\
\text { to } 2025 \text { by Vietnamese agencies }\end{array}$ & Reference sources \\
\hline Hydro & $84 \mathrm{TWh} / \mathrm{yr}\left({ }^{1}\right)$ & & & \\
\hline $\begin{array}{l}\text { + Large \& medium hydro (>30 MW) } \\
+ \text { Small hydro }(<30 \mathrm{MW}) \\
+ \text { Mini hydro }(<1 \mathrm{MW})\end{array}$ & $\begin{array}{l}18-20 \mathrm{GW} \\
2-4 \mathrm{GW} \\
100 \mathrm{MW}\end{array}$ & $\begin{array}{l}\text { Approximately } 4200 \mathrm{MW} \text {, } \\
\text { equivalent to } 18 \mathrm{TWh} / \mathrm{yr} \text {, } \\
\text { exploited from hydro }\end{array}$ & $\begin{array}{c}16.6 \mathrm{GW} \text { by } 2020 \\
2.5-3.2 \mathrm{GW}\end{array}$ & $\begin{array}{l}\text { Electricity of Vietnam, 2006a, c; } \\
\text { Institute of Energy, 2006b, c; Nguyen } \\
\text { Khac, } 2007\end{array}$ \\
\hline Hydro pump storage & $10.2 \mathrm{GW}$ & No & $10.2 \mathrm{GW}$ & $\begin{array}{l}\text { Electricity of Vietnam 2006a, c; } \\
\text { Institute of Energy, 2006b }\end{array}$ \\
\hline Geothermal & $1.4 \mathrm{GW}\left({ }^{2}\right)$ & No & 300-400 MW by 2020 & $\begin{array}{l}\text { Hoang, H. Quy (1998); Hoang and Ho } \\
\text { (2000); Institute of Energy 2006b, c }\end{array}$ \\
\hline Wind energy & $120.5 \mathrm{GW}\left({ }^{4}\right)$ & No & $550 \mathrm{MW}$ & $\begin{array}{l}\text { TrueWind Solutions 2001; Khanh } \\
\text { 2007a; Institute of Energy, 2006b, c }\end{array}$ \\
\hline Solar energy & $1 \mathrm{GW}\left({ }^{3}\right)$ & No & 2-3 MW & $\begin{array}{l}\text { PREGA (2004); Institute of Energy, } \\
\text { 2006b, c }\end{array}$ \\
\hline Rice husk & $250 \mathrm{MW}$ & No & & Nguyen L.T, and Q.C. Tran 2004; \\
\hline Paddy straw & $550 \mathrm{MW}$ & No & $500 \mathrm{MW}$ & Enerteam 2001; BCSE (2005); \\
\hline Bagasse & $200 \mathrm{MW}$ & No & & Institute of Energy, 2006a,b, c \\
\hline Wood residue & $100 \mathrm{MW}$ & No & & \\
\hline
\end{tabular}


Table 2: Characteristics of selected candidate generation technologies

\begin{tabular}{|c|c|c|c|c|c|}
\hline Candidate plants & $\begin{array}{c}\text { Capital cost } \\
(\$ / \mathrm{kW})\end{array}$ & $\begin{array}{c}\text { Efficiency } \\
\text { (\%) }\end{array}$ & $\begin{array}{c}\text { Fixed O\&M cost } \\
\text { (\$/kWmonth) }\end{array}$ & $\begin{array}{l}\text { Variable O\&M } \\
\text { cost (\$/MWh) }\end{array}$ & $\begin{array}{l}\text { Emission factor } \\
\text { (kg CO} / 2 / \mathrm{MWh})\end{array}$ \\
\hline Conventional coal & 1100 & 40 & 2.8 & 0.15 & 880 \\
\hline Supercritical coal & 1200 & 43 & 2.8 & 0.15 & 800 \\
\hline IGCC coal & 1300 & 45 & 3.55 & 0.15 & 704 \\
\hline NGCC gas & 700 & 54.63 & 1.98 & 0.99 & 370 \\
\hline Steam Oil & 900 & 43.57 & 1.63 & 1.48 & 730 \\
\hline Solar grid connected & 5500 & 100 & 2.5 & 0 & 0 \\
\hline Wind turbine & $1000-1300$ & 100 & 1.35 & 0 & 0 \\
\hline Geothermal & $1700-2000$ & 100 & 2.38 & 0 & 0 \\
\hline Very large hydro & 1120 & 100 & 0.54 & 0 & 0 \\
\hline Medium and large hydro & $1100-1500$ & 100 & 0.76 & 0 & 0 \\
\hline Small and mini hydro & $1200-1600$ & 100 & 1.5 & 0 & 0 \\
\hline Bagasse direct combustion & 850 & 23 & 3.58 & 5 & 71.64 \\
\hline Biomass IGCC & 1600 & 38.30 & 3.75 & 2.9 & 71.64 \\
\hline Wood IGCC & 1600 & 38.30 & 3.75 & 2.9 & 71.64 \\
\hline
\end{tabular}

Source: Institute of Energy (2005, 2006a, b, c), Electricity of Vietnam (2006a, b)

Table 3: Fuel prices (based on 2005) assumed in scenarios and in sensitivity analysis in the study

\begin{tabular}{|c|c|c|c|c|}
\hline \multirow{2}{*}{ Fuel type } & \multicolumn{2}{|c|}{ Scenario analysis } & \multicolumn{2}{|c|}{ Sensitivity analysis } \\
\hline & Fuel prices (\$/Gcal) & Escalation rate (\%) & Fuel prices (\$/Gcal) & Escalation rate (\%) \\
\hline Domestic coal (Anthracite) & 5 & 1.5 & 7.142 & 1.5 \\
\hline Imported coal (Bitum) & 6.15 & 1 & 9.23 & 1 \\
\hline Imported FO & 28.37 & 2 & 50.66 & 2 \\
\hline Imported DO & 30.79 & 2 & 56.7 & 2 \\
\hline Domestic natural gas & 15.87 & 2 & 17.46 & 2 \\
\hline Imported natural gas & 18.25 & 1.5 & 23.8 & 1.5 \\
\hline Bagasse & 0.781 & 1 & 0.781 & 1 \\
\hline Rice husk & 0.71 & 1 & 0.71 & 1 \\
\hline Paddy Straw & 0.625 & 1 & 0.625 & 1 \\
\hline Wood residue & 4.4 & 1 & 4.4 & 1 \\
\hline
\end{tabular}

Source: Institute of Energy (2005, 2006a, b, c), Electricity of Vietnam (2006a, b), World Energy Outlook, IEA 2006. 
Table 4: Estimated electricity load demand in different scenarios for the period of 2010-2030. The same transmission and distribution loss (\%) and used electricity (\%) are applied in all three scenarios.

\begin{tabular}{lcccccc}
\hline \multicolumn{1}{c}{ Items } & Scenario & $\mathbf{2 0 1 0}$ & $\mathbf{2 0 1 5}$ & $\mathbf{2 0 2 0}$ & $\mathbf{2 0 2 5}$ & $\mathbf{2 0 3 0}$ \\
\hline Peak load demand (MW) & Average & 18947 & 31037 & 46696 & 68416 & 83165 \\
Peak load demand (MW) & High & 19730 & 32430 & 48570 & 70790 & 86620 \\
Peak load demand (MW) & Low & 17940 & 27639 & 39286 & 55376 & 68473 \\
Transmission and distribution loss (\%) & Common & 10.8 & 9.6 & 8.5 & 7.5 & 7.5 \\
Used electricity (\%) & Common & 3.0 & 3.6 & 4.0 & 4.2 & 4.3 \\
\hline Source: Institute of Energy $(2006 \mathrm{~b}, \mathrm{~b}, \mathrm{c}, \mathrm{d})$, Electricity of Vietnam $(2006 \mathrm{a})$ & & & &
\end{tabular}

Source: Institute of Energy (2006a, b, c, d), Electricity of Vietnam (2006a)

Table 5: Quantitative estimates and assumptions of fuels (domestic and imported) and electricity import to meet electricity demand in Vietnam during 2010-2030.

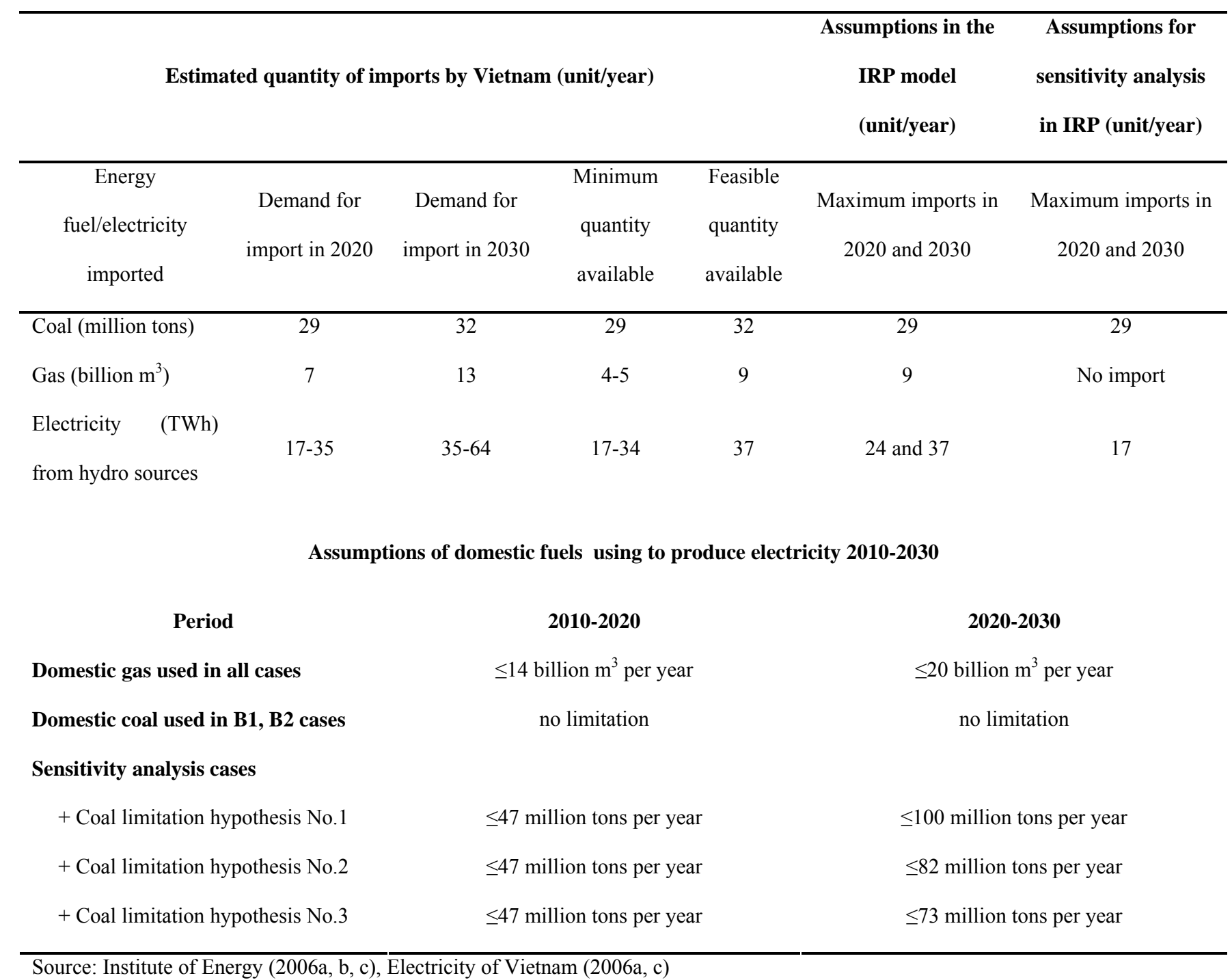


Table 6: Electricity capacity generation in Vietnam, 2010-2030. B1: with no RETs. B2: with RETs. Simulations of the Vietnamese power sector were carried out using the IRP model.

\begin{tabular}{|c|c|c|c|c|c|c|c|c|c|c|}
\hline & \multicolumn{3}{|c|}{ Renewable sources } & \multicolumn{6}{|c|}{ Fossil fuel sources } & \multirow[b]{2}{*}{ Total } \\
\hline & RETs & $\begin{array}{l}\text { Large } \\
\text { Hydro }\end{array}$ & $\begin{array}{l}\text { Hydro } \\
\text { Pump } \\
\text { Storage } \\
\end{array}$ & $\begin{array}{c}\text { Domestic } \\
\text { Coal }\end{array}$ & $\begin{array}{c}\text { Imported } \\
\text { Coal }\end{array}$ & $\begin{array}{c}\text { Domestic } \\
\text { Gas }\end{array}$ & $\begin{array}{c}\text { Imported } \\
\text { Gas }\end{array}$ & Oil & $\begin{array}{l}\text { Electricity } \\
\text { imported }\end{array}$ & \\
\hline \multicolumn{11}{|c|}{ Generation capacity installed (MW) } \\
\hline B1 & 0 & 14124 & 10200 & 35394 & 12000 & 13200 & 7500 & 600 & 6815 & 99833 \\
\hline B2 & 4432 & 14124 & 10200 & 31194 & 12000 & 13200 & 7500 & 600 & 6815 & 100065 \\
\hline \multicolumn{11}{|c|}{ Electricity generation (GWh) } \\
\hline B1 & 0 & 1190299 & 172234 & 2235498 & 987940 & 1887615 & 509032 & 21405 & 385559 & 7389582 \\
\hline B2 & 369826 & 1190300 & 172217 & 1906878 & 964418 & 1878085 & 490006 & 21405 & 376974 & 7370108 \\
\hline
\end{tabular}

Table 7: Technical, economic, and environmental comparison between the B1 scenario (no RETs) and the B2 scenario (with RETs) for the period 2010-2030. Simulations of the Vietnamese power sector were carried out using the IRP model.

\begin{tabular}{|c|c|c|c|c|}
\hline Point of comparison & $\begin{array}{c}\text { Without } \\
\text { renewables }\end{array}$ & $\begin{array}{c}\text { With } \\
\text { renewables }\end{array}$ & Avoided (absolute) & Avoided (\%) \\
\hline \multicolumn{5}{|l|}{ 1. Electricity utility implications } \\
\hline Total generation capacity added over $2010-2030$ (MW) & 81788 & 82020 & -232 & -0.28 \\
\hline Total generation capacity installed up to 2030 (MW) & 99833 & 100065 & -232 & -0.23 \\
\hline Total electricity generation over 2010-2030 (TWh) & 7389.6 & 7370.1 & 19.5 & 0.26 \\
\hline Average loss of load probability (\%) & 0.05 & 0.01 & 0.04 & 83.15 \\
\hline Average expected energy not served (GWh) & 57.69 & 8.51 & 49.18 & 85.25 \\
\hline Average thermal efficiency $(\%)$ & 46.72 & 47.20 & -0.48 & -1.03 \\
\hline Average capacity factor $(\%)$ & 64.69 & 64.31 & 0.38 & 0.59 \\
\hline \multicolumn{5}{|c|}{ 2. Implications for energy resource conservation and energy security } \\
\hline \multicolumn{5}{|l|}{ Domestic fuel consumption over 2010-2030 } \\
\hline - Coal (million tons) & 971 & 830 & 141.4 & 14.56 \\
\hline - Gas (billion $\mathrm{m}^{3}$ ) & 296 & 295 & 1.53 & 0.52 \\
\hline
\end{tabular}

Imported fuel consumption over 2010-2030 


\begin{tabular}{|c|c|c|c|c|}
\hline Point of comparison & $\begin{array}{c}\text { Without } \\
\text { renewables }\end{array}$ & $\begin{array}{c}\text { With } \\
\text { renewables }\end{array}$ & Avoided (absolute) & Avoided (\%) \\
\hline - Coal (million tons) & 311 & 304 & 7.41 & 2.38 \\
\hline - Gas (billion $\mathrm{m}^{3}$ ) & 78 & 75 & 2.93 & 3.74 \\
\hline - Oil (million tons) & 5.02 & 5.02 & 0.00 & 0.00 \\
\hline Imported electricity during 2010-2030 (TWh) & 385.6 & 377 & 8.6 & 2.23 \\
\hline \multicolumn{5}{|l|}{ 3. Economic Implications } \\
\hline Fuel and variable O\&M cost during 2010-2030 (million \$) & 26864 & 25748 & 1,116 & 4.15 \\
\hline Total discounted planning cost during 2010-2030 (million \$) & 48167 & 46905 & 1,262 & 2.62 \\
\hline Average incremental cost AIC (\$cent/kWh) & 4.01 & 3.98 & 0.03 & 0.75 \\
\hline Long run average cost LRAC $(\$ c e n t / k W h)$ & 2.97 & 2.90 & 0.07 & 2.36 \\
\hline \multicolumn{5}{|l|}{ 4. Environmental Implications } \\
\hline \multicolumn{5}{|l|}{ Total emissions during 2010-2030 } \\
\hline - $\mathrm{CO}_{2}$ emission (Mton) & 3825 & 3512 & 313 & 8.20 \\
\hline - $\mathrm{SO}_{2}$ emission (Kton) & 2601 & 2520 & 81 & 3.13 \\
\hline - $\mathrm{NO}_{\mathrm{X}}$ emission (Kton) & 6015 & 5767 & 248 & 4.12 \\
\hline
\end{tabular}


Table 8: Power capacity and electricity generation by type of renewables and fossil fuels generation sources in Vietnam, 2010-2030. B2: baseline scenario using RETs. SA1-SA7: different sensitivity analysis scenarios. Simulations were carried out using the IRP model.

\begin{tabular}{|c|c|c|c|c|c|c|c|c|c|c|c|c|}
\hline Scenarios & $\begin{array}{l}\text { Mini } \\
\text { hydro }\end{array}$ & $\begin{array}{l}\text { Small } \\
\text { Hydro }\end{array}$ & Biomass & Wood & Wind & $\begin{array}{c}\text { Geo- } \\
\text { thermal }\end{array}$ & Solar & $\begin{array}{l}\text { Large } \\
\text { Hydro }\end{array}$ & $\begin{array}{c}\text { Dom- } \\
\text { Coal }\end{array}$ & $\begin{array}{l}\text { Imp- } \\
\text { Coal }\end{array}$ & Dom-Gas & Imp-Gas \\
\hline \multicolumn{13}{|c|}{ Total generation capacity in 2030 (MW) } \\
\hline B2: & 0 & 2032 & 1000 & 0 & 0 & 1400 & 0 & 14124 & 31194 & 12000 & 13200 & 7500 \\
\hline SA1: No fuel gas import & 0 & 2032 & 1000 & 0 & 0 & 1400 & 0 & 14124 & 39294 & 12000 & 13200 & - \\
\hline $\begin{array}{l}\text { SA2: Limited electricity import (maximum } \\
\text { amount of } 17 \mathrm{TWh} / \text { year) }\end{array}$ & 0 & 2032 & 1000 & 0 & 0 & 1400 & 0 & 14124 & 38394 & 12000 & 13200 & 3750 \\
\hline SA3: Low load demand & 0 & 2032 & 1000 & 0 & 0 & 1400 & 0 & 14124 & 14994 & 12000 & 13200 & 7500 \\
\hline SA4: High load demand & 0 & 2032 & 1000 & 0 & 0 & 1400 & 0 & 14124 & 35094 & 12000 & 13200 & 7500 \\
\hline SA5: High fuel prices & 100 & 2432 & 1000 & 0 & 0 & 1400 & 0 & 14803 & 36294 & 12000 & 13200 & 7500 \\
\hline $\begin{array}{l}\text { SA6: High fuel prices }+ \text { wind technology cost falls } \\
\text { to } 900 \mathrm{US} \$ \mathrm{~kW}\end{array}$ & 100 & 2332 & 1000 & 0 & 4622 & 1400 & 0 & 14803 & 36594 & 12000 & 13200 & 7500 \\
\hline $\begin{array}{l}\text { SA7: High fuel prices }+ \text { wood energy technology } \\
\text { cost falls to } 1500 \mathrm{US} \$ / \mathrm{kW}\end{array}$ & 100 & 2332 & 1000 & 100 & 0 & 1400 & 0 & 14803 & 36594 & 12000 & 13200 & 7500 \\
\hline $\begin{array}{l}\text { SA8:=SA1+SA2+SA5+no limited domestic coal } \\
\text { supply }\end{array}$ & 100 & 3917 & 1000 & 0 & 0 & 1400 & 0 & 17253 & 38094 & 12000 & 13950 & - \\
\hline $\begin{array}{l}\text { SA9:=SA1+SA2+SA5+ limited domestic coal } \\
\text { supply as hypothesis No.1 }\end{array}$ & 100 & 3917 & 1000 & 100 & 7888 & 1400 & 0 & 18089 & 34894 & 12000 & 13950 & - \\
\hline $\begin{array}{l}\text { SA10: }=\mathrm{SA} 1+\mathrm{SA} 2+\mathrm{SA} 5+\text { limited domestic coal } \\
\text { supply as hypothesis No. } 2\end{array}$ & 100 & 3917 & 1000 & 100 & 22276 & 1400 & 0 & 17561 & 28394 & 12000 & 13950 & - \\
\hline $\begin{array}{l}\text { SA11:=SA1+SA2+SA5+ limited domestic coal } \\
\text { supply as hypothesis No.3 }\end{array}$ & 100 & 3917 & 1000 & 100 & 29478 & 1400 & 0 & 17561 & 25394 & 12000 & 13950 & - \\
\hline
\end{tabular}




\begin{tabular}{|c|c|c|c|c|c|c|c|c|c|c|c|c|}
\hline Scenarios & $\begin{array}{l}\text { Mini } \\
\text { hydro }\end{array}$ & $\begin{array}{l}\text { Small } \\
\text { Hydro }\end{array}$ & Biomass & Wood & Wind & $\begin{array}{c}\text { Geo- } \\
\text { thermal }\end{array}$ & Solar & $\begin{array}{l}\text { Large } \\
\text { Hydro }\end{array}$ & $\begin{array}{l}\text { Dom- } \\
\text { Coal }\end{array}$ & $\begin{array}{l}\text { Imp- } \\
\text { Coal }\end{array}$ & Dom-Gas & Imp-Gas \\
\hline \multicolumn{13}{|c|}{ Total electricity generation during 2010-2030 (GWh) } \\
\hline B2: & 0 & 146497 & 99061 & 0 & 0 & 124268 & 0 & 1190300 & 1906878 & 964418 & 1878085 & 490006 \\
\hline SA1: No gas imported & 0 & 154954 & 99061 & 0 & 0 & 124268 & 0 & 1190304 & 2505917 & 985802 & 1757930 & - \\
\hline $\begin{array}{l}\text { SA2: Limited electricity imported (maximum } \\
\text { amount of } 17 \mathrm{TWh} / \text { year) }\end{array}$ & 0 & 152135 & 99061 & 0 & 0 & 124268 & 0 & 1190302 & 2405553 & 983664 & 1836735 & 200901 \\
\hline SA3: Low load demand & 0 & 132678 & 96129 & 0 & 0 & 124268 & 0 & 1177379 & 1023480 & 857499 & 1858525 & 344188 \\
\hline SA4: High load demand & 0 & 148511 & 99061 & 0 & 0 & 124268 & 0 & 1190303 & 2146287 & 983663 & 1875945 & 488037 \\
\hline SA5: High fuel prices & 4917 & 167911 & 99061 & 0 & 0 & 124268 & 0 & 1224489 & 2187057 & 964419 & 1911078 & 96900 \\
\hline $\begin{array}{l}\text { SA6: High fuel prices }+ \text { wind technology cost falls } \\
\text { around } 900 \mathrm{US} \$ \mathrm{~kW}\end{array}$ & 4917 & 162994 & 99061 & 0 & 240244 & 124268 & 0 & 1224489 & 2283237 & 878882 & 1913122 & 89596 \\
\hline $\begin{array}{l}\text { SA7: High fuel prices }+ \text { wood energy technology } \\
\text { cost falls around } 1500 \mathrm{US} \$ \mathrm{~kW}\end{array}$ & 4728 & 162994 & 99061 & 10612 & 0 & 124268 & 0 & 1224490 & 2283585 & 878882 & 1907449 & 87671 \\
\hline SA8: $=\mathrm{SA} 1+\mathrm{SA} 2+\mathrm{SA} 5+$ no limited domestic coal & 4917 & 200482 & 99061 & 0 & 0 & 124268 & 0 & 1303867 & 2550523 & 819007 & 1875183 & - \\
\hline $\begin{array}{l}\text { SA9: }=\mathrm{SA} 1+\mathrm{SA} 2+\mathrm{SA} 5+\text { limited domestic coal } \\
\text { supply as hypothesis No.1 }\end{array}$ & 4917 & 200482 & 99061 & 2948 & 21883 & 124268 & 0 & 1315901 & 2535185 & 816868 & 1856990 & - \\
\hline $\begin{array}{l}\text { SA10: }=\mathrm{SA} 1+\mathrm{SA} 2+\mathrm{SA} 5+\text { limited domestic coal } \\
\text { supply as hypothesis No.2 }\end{array}$ & 4917 & 200482 & 99061 & 5159 & 101434 & 124268 & 0 & 1304684 & 2418797 & 819007 & 1881313 & - \\
\hline $\begin{array}{l}\text { SA11:=SA1+SA2+SA5+ limited domestic coal } \\
\text { supply as hypothesis No.3 }\end{array}$ & 4917 & 200482 & 99061 & 5896 & 161836 & 124268 & 0 & 1309143 & 2347359 & 819007 & 1884104 & - \\
\hline
\end{tabular}


Figure 1. Distribution of electricity generation sources in Vietnam for the period 2005-2010

Source: Institute of Energy, 2006b

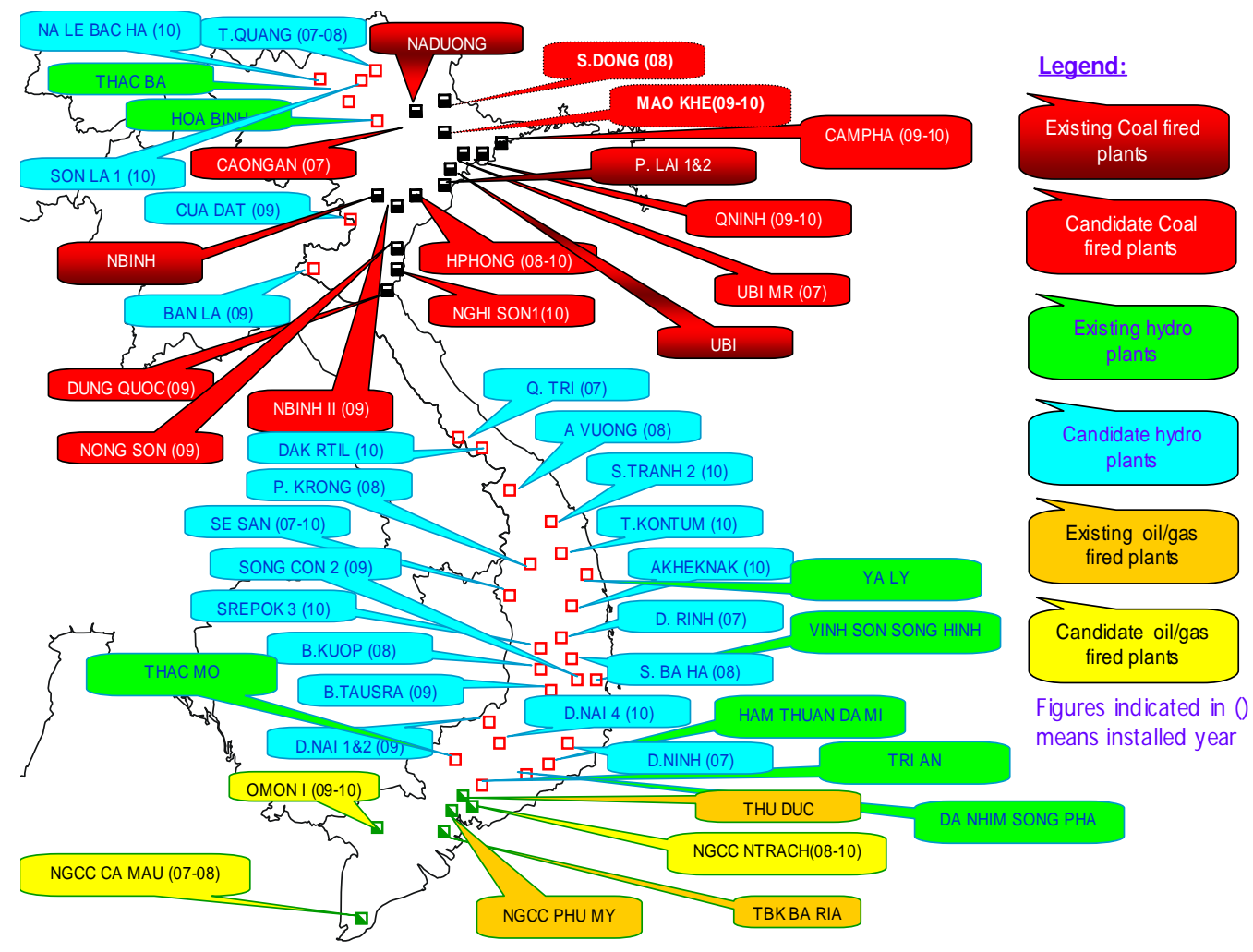

Figure 2. History and forecasts of electricity energy and peak load demand in Vietnam, 1995 to 2030. Source: Institute of Energy (2006b, c, d)

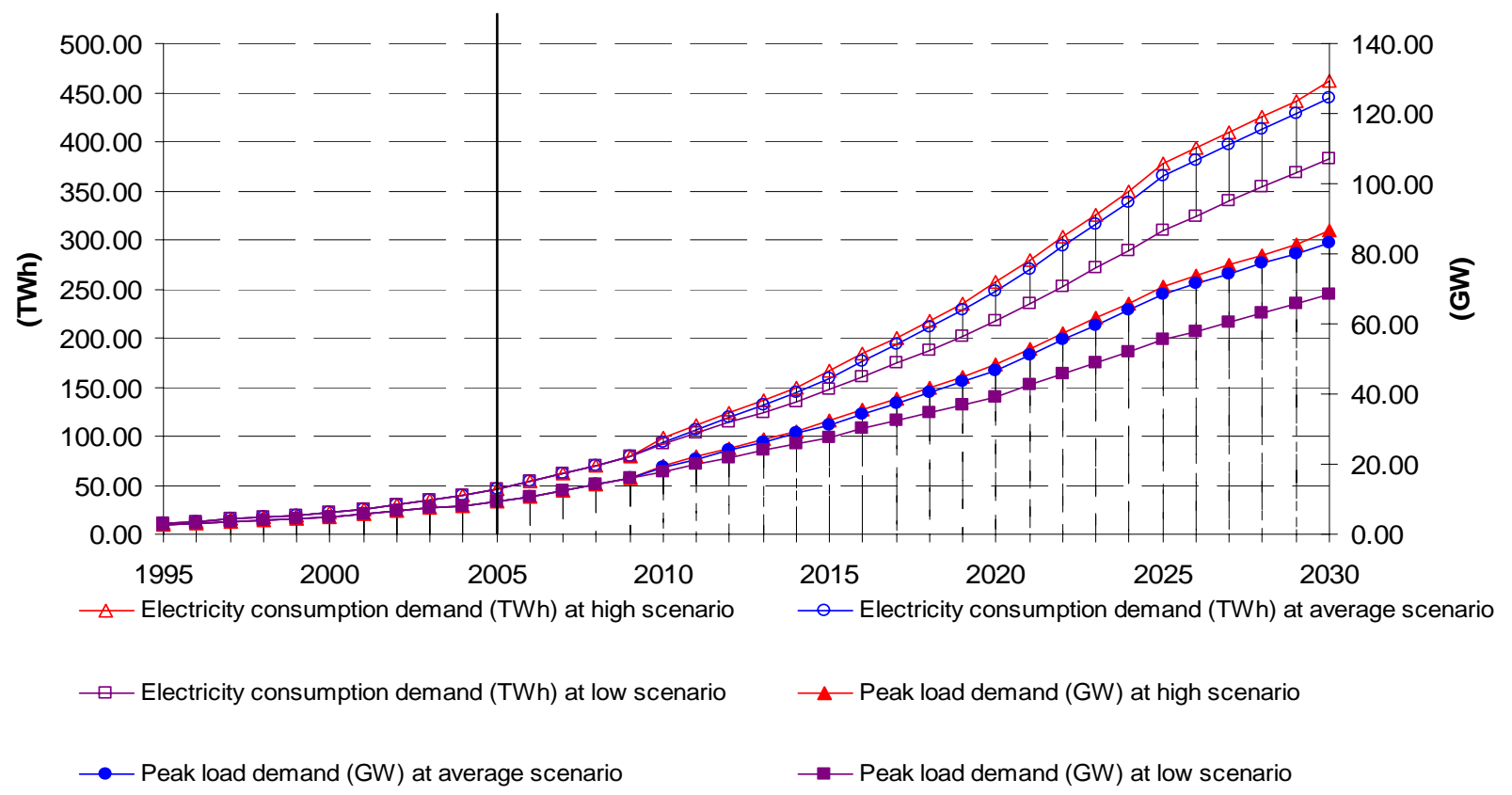


Figure 3. Annual fuel demand of domestic natural gas (billion $\mathrm{m}^{3}$ ) and coal (million tons) for electricity generation during 2010-2030 in the B1 and B2 scenarios

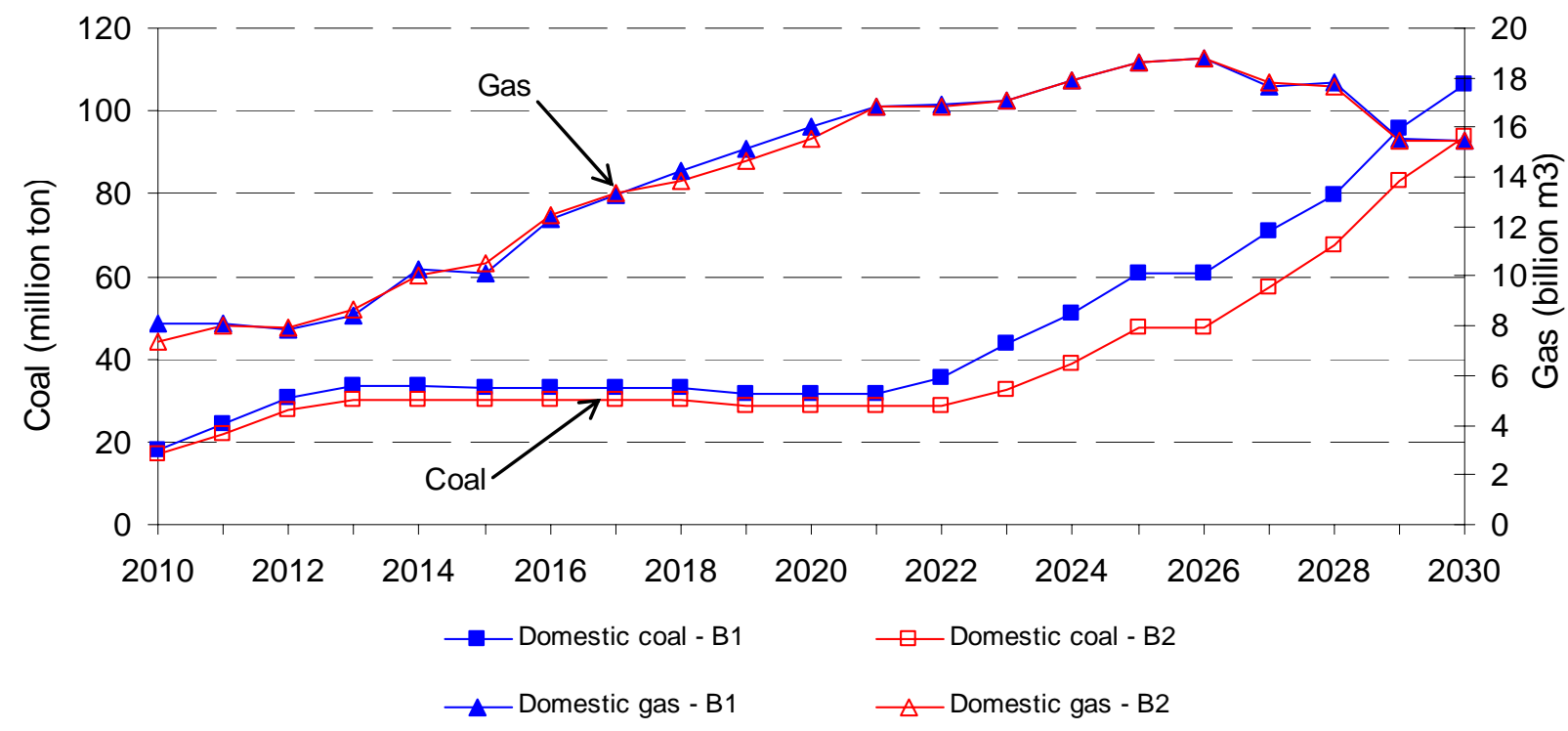

Figure 4. The annual demand for imported natural gas (billion $\mathrm{m}^{3}$ ), coal (million tons), and electricity $(\mathrm{GWh})$ for electric power generation during 2010-2030 in the B1 and B2 scenarios

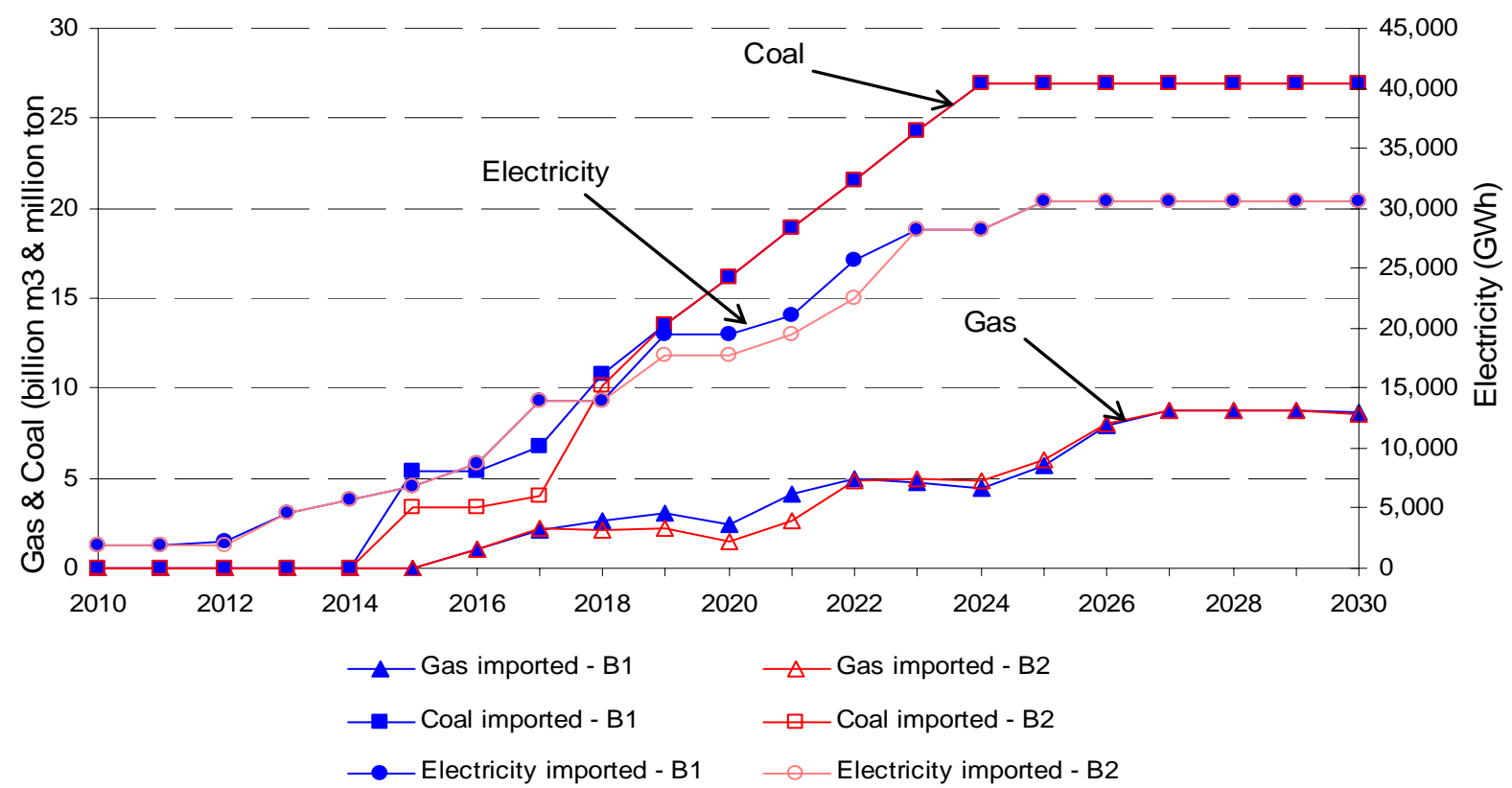


Figure 5. Annual component costs of electricity generation (GWh) during 2010-2030 in the B1 and $\mathrm{B} 2$ scenarios

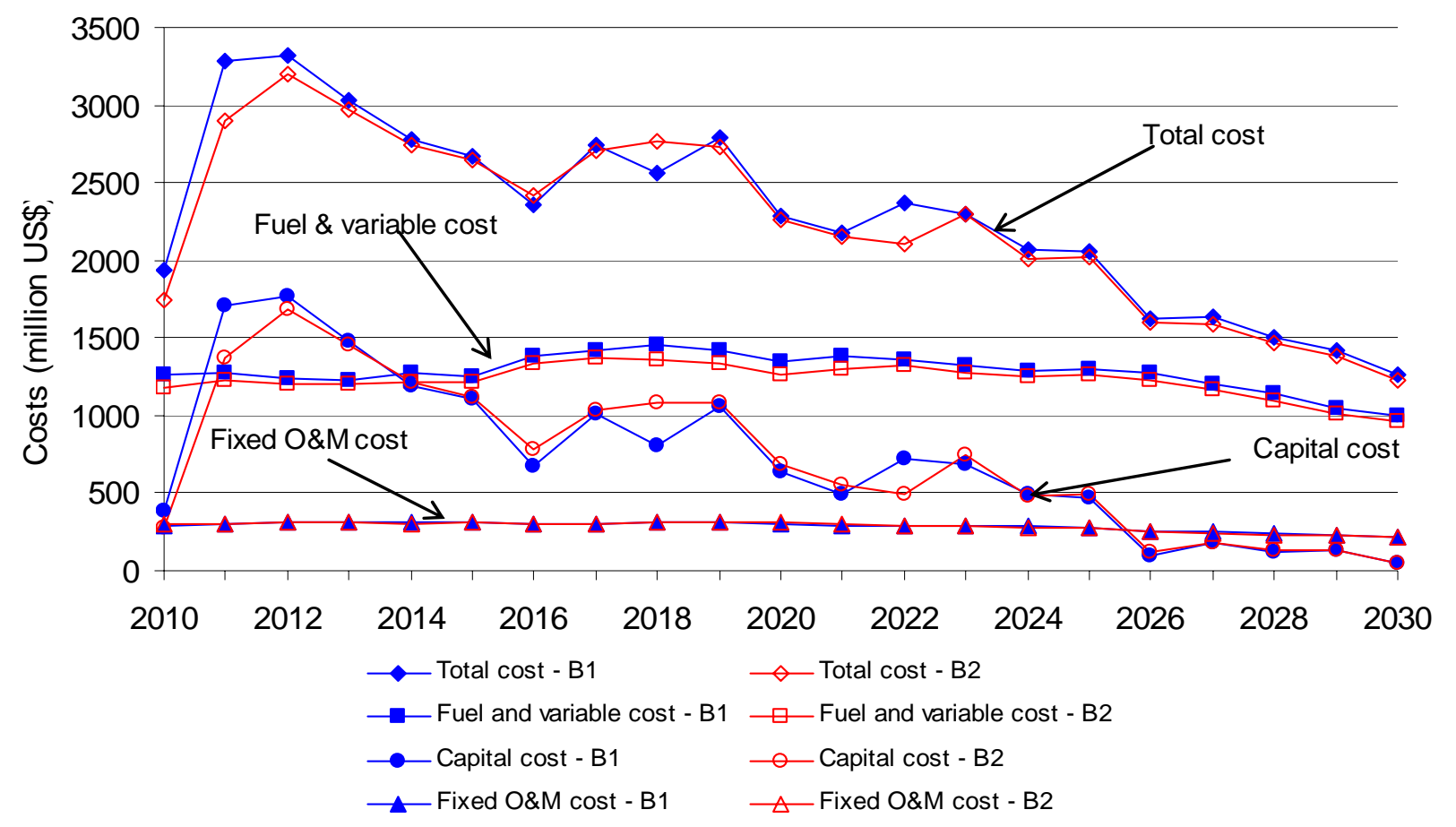

